\title{
The Problem of Gender and Sensitive Use of the Language in Kazakhstan: The Case of German
}

\author{
Gulnar Kulmukhambetovna Ismagulova (Corresponding author) \\ Kostanay State Pedagogical Institute, Kostanay, Kazakhstan \\ E-mail: gulnar.k.ismagulova@mail.ru \\ Viktoriya Valerievna Danilova \\ Kostanay State Pedagogical Institute, Kostanay, Kazakhstan \\ Kenzhigul Kunusbaevna Segizbaeva \\ Kostanay State Pedagogical Institute, Kostanay, Kazakhstan \\ Bibikul Mazanovna Utegenova \\ Kostanay State Pedagogical Institute, Kostanay, Kazakhstan \\ Yuliya Borisovna Grigorova \\ Kostanay State Pedagogical Institute, Kostanay, Kazakhstan
}

Received: 12-04-2016

Accepted: 29-06-2016

Published: 01-09-2016 doi:10.7575/aiac.ijalel.v.5n.5p.246

Advance Access Published: July 2016

URL: http://dx.doi.org/10.7575/aiac.ijalel.v.5n.5p.246

\begin{abstract}
In this article the problem of language asymmetry and possibility of the gender and sensitive use of the Kazakh and Russian languages in the territory of Kazakhstan is discussed. One of the aspects of gender equality in society is also the language policy. Authors also suggest discussing this subject, involving experience of feministic linguistics of other countries, and first of all, of Germany. Gender and sensitive use of the language in oral and written communication is especially urgent for Kazakhstan as culturally determined features of the language policy in this cultural space have a gap due to the low level of special attention paid to gender democracy in the language. But at the same time, it creates a vast platform for further researches in this direction. Both language and political activity are determined by the fact that these intentions are part of the general social transformations in our society. An integrated approach to the analysis of gender and sensitive use of the language in Kazakhstan, systematization of theoretical knowledge demands, studying foreign experience in gender reform of the language and it is impossible to be implemented without linguistic data from other languages. Their critical judgment will allow avoiding problems connected with implementation of this policy.
\end{abstract}

Keywords: language asymmetry, gender, gender equality, feminization, neutralization

\section{Introduction}

Language and thinking are closely interconnected. Language forms and expressions influence our representations. Language reflects social values and fixes symmetry and asymmetry in its use, equality or an inequality of the language use. Language equality on a gender base is today among other things of the main priority in the process of establishing equality in society due to changes in the language that promote transformations in society. "Also Sprache ändert sich, weil wir unsere Sprache ändern, wenn sie unseren Bedürfnissen nicht mehr entspricht. Wir können sie auch bewusst ändern und wir müssen sie ändern“ (Trömmel-Plötz, 1992). So, the principle of gender equality is an inevitable condition of modern society, and the gender and correct formulation has to be relevant to requirements of time and society including the basic principles of written and oral communication in all languages.

In the late sixties of the 20th century there was a direction in linguistics (mainly in the USA, Australia and Germany) called 'the feministic criticism of the language' or 'feministic linguistics'. Within feminist movement of the seventieths and eighties of the $20^{\text {th }}$ century the question of social value of a gender of the personality was put forward. Furthermore, a problem of a change in the language structure as the purpose of usage has achieved certain results in feministic linguistics. Debate and requirements of feminist linguists concerning making women "visible and heard" (transparent) in the language, especially in public and its public use, gained results (e.g. Mitarbeiterinnen und Mitarbeiter oder Team; Lehrer und Lehrerin oder Lehrkraft; Leserinnen und Leser). The list of identifications concerning a female gender is constantly replenished. For example, since 2005 with the election of Angela Merkel one more identification as Kanzlerin has appeared. 
Professors Senta Trömmel-Plötz and Luise F. Pusch were the pioneers of feministic linguistics in Germany who transformed the public consciousness so that initially there are two genders and a masculine one can't be common for both genders. Their long-term debate about political and social ability of women helped the process of representation of women within all spheres of life. (Pusch, 1984; Trömel-Plötz, 1988). One of the existing postulates tells about "doing gender" as a bilateral process. "Produktion und Rezeption sind danach interagierende Komponenten, die letztlich nur gemeinsam "erfolgreiches" doing gender gewährleisten (Gottburgsen, 2000).

Numerous examples from various areas of social and political life are the proof of that the modern languages have been strongly changed. Due to great efforts by the USA (Guidelines for Equal Treatment of the Sexes in Social Studies Textbooks, 1972), Canada, Great Britain, Australia issued recommendations on elimination of the sexual use of the language in the professional environment, public institutions. In Germany (1974 and 1975), France and Austria, national and regional recommendations on linguistically equal use of gender supported by various legislative authorities and the international agreements were issued. After foundation of the Women's communicative center in Wiesbaden (Wiesbadener Frauenkommunikationszentrums) in 1990 issues of the gender and specific use of language were strictly brought up, e.g. it was connected with problems of legal and administrative language, participation of men and women in political discourse (Margot Brunner, 1992, I. Auflage, 1992). Among active supporters were the following: the president of German Bundestag - Prof. Dr. R. Süssmuth, Stadträtin E. Mikfeld, linguist, Prof. Dr. L F. Pusch, the head of editorial board of Duden - Prof. Dr. G. Drosdowski who were engaged in the process of changes in the language use.

Gender linguistics is a rather young branch of linguistics not only in Kazakhstan, but also in the former Soviet Union. It was found in the ninetieth of the 20th century. Modern researches illustrate the relevance and urgency of the topic of linguistically equal gender use (Horvath, L.K., Merkel, E.F., Maass, A. and Sczesny, S.,2016) including possible ways of avoiding linguistic female stereotyping and discrimination (Sczesny S, Formanowicz M., Moser, F., 2016), etc.

\section{Methodology}

The essential contribution to the development of gender linguistics was made by Dr. A. Kirilina (Kirilina, 1997, 1998, 2000), I.I. Chaleeva, O. Voronina (Voronina, 2001), etc.

The question of the need of Gender Mainstreaming for language policy in the former Soviet Union has been thoroughly studiedby Tolstokorova A.V. in the article "Gender and sensitive reform of language as an element of global social policy: experience of the international women's movement" consecrates relevance of a problem of linguistic gender equality in the former Soviet Union and need of development of gender approach to language policy aimed at dealing with language sexism. "In the former Soviet Union special attention was not paid to linguistic aspect of gender equality, and discussion of a problem in scientific and popular publications still has sporadic character" (Tolstokorova, 2005).

In world practice woman is viewed as the mistress of the fate with active living position who can not only assert the rights in society, but also offer new approaches to the solution of urgent problems. Socio-political changes in society gradually influence gender way and the system of language. The gender marked lexicon includes the following words in the Russian language, for example: "the business lady", "the businesswoman", "the iron lady", "all people are sisters" ( analogous to the journal as an antipode to the statement that "all people are brothers"). The word "feminist" ceased to be perceived as something far, introduced from the West and hostile to national identity. In the Kazakh language analogy for above mentioned phrases are called nominations of the lexeme "the isker aiel", formed by "isker"/ "the businessman" and "aiel"/ "woman". Other identifications in language background have not been observed at the moment.

The fact of increase of women in political arena of Kazakhstan does not influence language background though the absence of grammatical category of gender in the Kazakh language due to visual absence of gender stratification in the Kazakh language. The use of borrowed words from Russian or English throughout the Russian language ("the minister", "the deputy") allows concluding that "the woman" has insufficient representation in the language background of the world of the Kazakh people, its "inclusion" into masculine gender.

Alongside with it, special names of professions related only to a female language has appeared: "medbibi" or "medbike"/ "nurse". Having carried out the component analysis, we came to a conclusion that the male in this case is not presented by a separate lexical unit ("med/medicine"; "bike (sh) means "young, unmarried woman" in the Kazakh language where initial meaning was "the daughter/girl out of a notable family", nowadays this word is used as a form of the address to a young girl; in this case equivalent to the word "sister" or "worker") and it cannot be "included" in female gender as the second component is gender marked. The word "the head nurse" / "aga medbibi" is of high interest. The word "aga" is polysemantic in the Kazakh language. This word refers to the identification of "the elder brother", the address to the one who is elder or the one who is dear, including the one who is senior on a military rank, for example, "aga - lieutenant / "the senior lieutenant". Therefore, the use of this component as identification of professional hierarchy is evident, though from above described it is concluded that the profession of the nurse is already gender marked and does not include a male gender.

\section{Linguistic situation in Kazakhstan}

The gender policy is a component of social policy of any democratic state. And the "female" policy is rather young concept of Kazakhstan and it has been used since 1994 till the moment of foundation of feministic league of Kazakhstan. History of development of female policy in world cultures (USA, Canada, Australia) has proved that language policy, namely gender aspect, plays an important role in female policy. 
At the moment national committee on issues on women and family, gender population policy under the leadership of the President of Kazakhstan coordinates work on implementation of gender policy in Kazakhstan. Its main objective is realization of a state policy concerning issues on family and equality of women and men in the context of strategy of development of Kazakhstan up to 2030, strategy of gender equality in Kazakhstan for 2006-2016 (the decree of the President of Kazakhstan dated November 29, 2005) and international treaties concerning family and gender equality. But, achievement of gender equality requires observance and formal legal equality in all spheres of life, one of which is, in our opinion, the gender and sensitive use of language.

However, the analysis of the catalog of educational resources of feministic league of Kazakhstan reflects the scope of researches in the field in the region concerning both languages (Kazakh and Russian). The majority of them are directed to assessment of the situation of women in Kazakhstan, development tendencies, a problem of unequal distribution of material and symbolical resources. For example, the works of Ashibaeva A.D. "Woman and social progress" (Ashibaeva, 1989); Balgosina R.O. "Female emensipation in Kazakhstan: historical experience and political period 1917-1941" (Balgoshina, 2001); Sarsembaeva R.B. "Market transformation of the Kazakhstani society: experience of the gender analysis" (Sarsembaeva, 2004); "Gender and political parties, instutute for the development of Kazakhstan" (2004); Concept of gender policy and purpose of century in Kazakhstan; The national commission on issues on family and women under the leadership of the President of Kazakhstan (2004), etc.

Concerning scientific researches on the topic of linguistic equality of genders we can name some works as Mamaeva G.B. "Features of the use of lexicon by women and men" (Mamaeva, 2003), G. Ismagulova "Linguocultural aspect of the gender relations: comparison of the German, Kazakh and Russian languages" (Ismagulova, 2005). Within studying of a problem G. Ismagulova brings up questions of linguocultural specifics of the gender relations in the Kazakh, Russian and German languages, representations of the gender relations in language background of the world, comparative analysis of paroemias of a gender perspectives in the specified languages.

Before discussing a question of the gender and legal use of the language in Kazakhstan, we would like to concern briefly the general language situation in Kazakhstan. With more than 120 nationalities, Kazakhstan is considered a polycultural society with 2 languages dominating in communication. Kazakh under the Constitution of RK in 1991 met the status of a state language. Russian in the territory of Kazakhstan is considered a language of international communication alongside with Kazakh. From here, written and oral communication is carried out under the law in 2 languages as it has been stated above in this article.

Gender and sensitive use of language in everyday spoken or written communication is especially relevant for Kazakhstan as culturally determined features of language policy in this cultural space have a gap due to the fact that special attention was not paid to gender democracy in the language. But at the same time, it creates an interesting platform for further researches in this direction. Language and political activity is determined by the fact that these aspirations are part of the general social transformations in our society.

Integrated approach to the analysis of gender and sensitive use of the language in Kazakhstan, systematization of theoretical knowledge demands studying foreign experience concerning gender reform of language and it is impossible without attraction of materials from other languages. Their critical judgment will allow avoiding possible problems

First of all, undertaking such researches, it would be desirable to use the tendencies of language transformations in Germany. The known social and linguistic factors connected with gender policy include:

- feminization (language transparency of women and men through the use of explicit forms);

- neutralization (use of the general forms). „Die erste Strategie kann offenbar auf Unterstützung durch sprachpolitische Maßnahmen rechnen, wenn in der betreffenden Sprachgemeinschaft bereits Tendenzen des Sprachwandels zu beobachten sind, ... (Marlis Helinger, 1985). „Die Strategie der Neutralisierung bietet sich dagegen an, wenn die betreffende Sprache keine Genussprache ist ..." (Marlis Helinger, 1985).

Feminization is a significant point applied to the language having developed gender system. The more intensive the syntactical aspect is expressed (articles, adjectives, pronouns, conjugation), the more significant is the position of the female gender in the language system (the Russian language). Understanding of the language as means of the social tool leads to the social and role functions of individuals in the society.

Thus, feminization can find application in our case concerning Russian (existence of a grammatical gender), and strategy of neutralization is applicable in Kazakh (absence of grammatical category). Besides, we find it possible to use creative innovations of the last years of the German linguists in disputable situations (Prof. Dr. Lann Hornscheidt, Humboldt Universität zu Berlin).

The strategy of neutralization is found in the case when the language has no gender distinction (the Kazakh language). We consider that not any linguistic culture can use one of these strategies in pure form. Consequently, for example, linguistic and cultural limitations in the use of the feminist expressions cannot be applied due to the style of the language (suffix 'sha'-'ma'in Russian in the words as bibliotekarsha (femane librarian) is consideres as vulgar out of the style). In this case most of the European linguists offer the use of the creative (innovative) approach.

On the basis of the studied experience we can develop further recommendations about the non-gender use of language in written and oral speech which will be based on lexical and grammatical structures of the Kazakh and Russian languages and partially with the use of creative approach. 


\section{Methods of research}

Issues of research allow and demand various research methods:

- empirical methods (open interviews, discussions, observation, written poll, verification of data);

- method of critical analysis;

- method of contrastive analysis.

Empirical methods (open interviews, discussions) as classical methods of social researches are also suitable for studying social opinion. Target group in this case includes people from various fields of activity. Poll has to show how society treats the gender equality in the Kazakh and Russian languages illustrating how expected changes in languages are important or will be apprehended.

Thus, poll will open new prospects or discussions about gained experience and will broaden the field of knowledge. The critical analysis of the presented literature in Kazakhstan and Germany gives the chance to define a status quo (problem) and offer practical alternatives.

The contrastive analysis will allow revealing what language reserves are available in both languages in order to make subsequent proposals on the use of the known strategy.

\section{Results and Discussion}

In our research we analyzed the linguistic situation and readiness of society for the linguistic change connected with gender equality and ongoing events.

We conducted a survey among 40 respondents (20 women and 20 men) of various professional spheres, this survey contained the following questions:

1. What is your profession? (the aim of the question was to find out the ways of self-identification of mainly women in their occupations).

2. How could you name your profession taking the gender identification into account? (the aim of the question was to figure out the abilities of respondents to name themselves on the base of gender identification).

3. Have you ever thought of gender identifications concerning professions in your language as male dominating? (the aim of the question was to present the social awareness of gender identification inequality)

The survey mentioned above represented the following results (see Table 1):

Table 1. Survey on the gender identification in professional sphere

\begin{tabular}{ll}
\hline Question & Answers \\
\hline What is your profession? & Laboratorian \\
& The Chairperson of the Department \\
& Lecturer \\
& Librarian \\
& Accountant \\
& Student \\
& \\
\hline How could you name your profession taking the & Woman laboratorian \\
gender identification into account? & The Chairwoman of the Department \\
& Woman lecturer \\
& Woman librarian \\
& Woman accountant \\
& Woman student \\
\hline $\begin{array}{l}\text { Have you ever thought of gender identifications } \\
\text { concerning professions in your language as male }\end{array}$ & No \\
dominating? & \\
\hline
\end{tabular}

The analysis of the survey proved the low level of awareness of the studied problem in Kazakhstani society. However, as it has been stated above the fairness of the language based on gender principle has been one of the factors for establishing equality in the society due to the changes in the language having the power of transformation in the community. For reaching gender equality it is necessary to follow formal legal equality in all human spheres, one of those is gender and sensitive use of the language.

The table below presents information on comparative analysis of the use of strategies aimed at reaching gender equality in the languages based on three chosen languages - German, Russian and Kazakh (see Table 2): 


\begin{tabular}{|c|c|c|c|c|}
\hline \multirow[t]{2}{*}{ Language } & \multirow[t]{2}{*}{$\begin{array}{l}\text { Grammatical } \\
\text { gender in the } \\
\text { language } \\
\text { (presence/absence) }\end{array}$} & \multirow[t]{2}{*}{$\begin{array}{l}\text { Lexical and semantic } \\
\text { properties }\end{array}$} & \multicolumn{2}{|l|}{ Strategies } \\
\hline & & & Feminization & Neutralization \\
\hline German & + & $\begin{array}{l}\text {... Damen und Herren! } \\
\text { Geschäftsmann/ } \\
\text { Geschäftsfrau }\end{array}$ & Lehrerin & $\begin{array}{l}\text { Lehrperson } \\
\text { Lehrkräfte } \\
\text { Direktion Leitung } \\
\text { Studierende }\end{array}$ \\
\hline Russian & + & $\begin{array}{l}\text {... Дамы и господа! (Damy } \\
\text { I gospoda! - Ladies and } \\
\text { Gentlemen!) } \\
\text { Бизнесмен/ бизнес-леди } \\
\text { (Biznesmen, Biznesledi - } \\
\text { Businessman, } \\
\text { Businesswoman) }\end{array}$ & $\begin{array}{l}\text { Адвокатша (Advocat- } \\
\text { sha, suffix -sha is } \\
\text { indicating the } \\
\text { belonging to the } \\
\text { feminine gender in } \\
\text { Russian) - woman } \\
\text { lawyer; } \\
\text { Учительница } \\
\text { (uchitel'nitsa) - woman } \\
\text { teacher; } \\
\text { Jабopaнтка } \\
\text { ( laborantka - } \\
\text { laboratory assistant - } \\
\text { according to the } \\
\text { analogy of manicurist, } \\
\text { knitter, lacemaker, } \\
\text { obstetrician (taken } \\
\text { from Classificatory of } \\
\text { professions and } \\
\text { occupations of } \\
\text { technical, professional } \\
\text { and higher education } \\
\text { SC RK 05-2008) }\end{array}$ & $\begin{array}{l}\text { Directory } \\
\text { Administration } \\
\text { Studentship (instead } \\
\text { of students) }\end{array}$ \\
\hline Kazakh & - & $\begin{array}{l}\text { (Khanymdar men myrzalar!- } \\
\text { Ladies and Gentlemen!) } \\
\text { (Medbike, medbibi- Woman } \\
\text { nurse, male nurse) } \\
\text { (Isker/Isker aiel - } \\
\text { Businessman, } \\
\text { Businesswoman) }\end{array}$ & $\begin{array}{l}\text { Cannot be possible due } \\
\text { to the absence of word- } \\
\text { building morphemes }\end{array}$ & $\begin{array}{l}\text { Isker qauym - } \\
\text { Business people } \\
\text { Stuidenttik qauym - } \\
\text { Studentship }\end{array}$ \\
\hline
\end{tabular}

Violation of gender equality is seen in everyday communication. Here are some examples:

Frequently used forms of address in written communication:

- Dear readers! (in the library)

- Dear teachers! (official letters from the authorities)

- $\quad$ The sick person (in the hospital)

- Nationality - Kazakh, Russian, German (questionnaire of Ministry of education and science of the Republic of Kazakhstan)

- Tatyana Arkhipova - a participant of ski competition (the Russian 'uchastnik', where '-nik' is a male indicating suffix - the course is News Programme on the "Alau" Channel, dated 18.03.16.

- Aiel azamattar! ('Women Citizens' as a direct Kazakh-English translation the course is Daua Programme, "Kazakhstan Channel”, dated 19.03.16.

\section{Conclusion}

Thus, the analysis of the relevant literature has allowed identifying linguistic and extra linguistic factors of gender reform of language in Kazakhstan.

On the basis of the gained experience it is necessary to develop further recommendations on non-gender use of the language both in written, and in oral communication which will be based on lexical and grammatical structures of Kazakh and Russian languages and partially with the use of creative approach.

In the nearest future more expanded interviewing at various levels is to be planned. Main questions to be discussed can be formulated as follows: what is the state of awareness of this subject in Kazakhstan? Who is in advance of this question: linguists, mass media or literature? This material will give an opportunity to analyze the attitude of society to a problem of the gender and equal use of language and its prospects as well. 


\section{References}

Ashibaeva, A.D. (1989). Woman and social progress. 176 p.

Balgosina, R.O. (2001). Female emensipation in Kazakhstan: historical experience and political period 1917-1941, Semipalatinsk, $172 \mathrm{p}$.

Bickes, H., Brunner, M. (1992). The native language without women? Man's language without Women? Wiesbaden, $144 \mathrm{p}$.

Brunner, K.M. Frank-Cyrus, Von M. (1998). The woman in language. Conversations on gender equivalently use of language. Wiesbaden: Society of German.

Classificatory of professions and occupations of technical, professional and higher education. SC RK. 05-2008

Gottburgsen, A. (2000).Stereotypic samples of linguistic 'doing gender'. Empirical research. Verlag GmbH publishing, $266 \mathrm{p}$.

Helinger, M. (1985). Changes in language and feministic language policy: international perspectives, Verlag GmbH publishing, Obladen.

Hellinger, M. (1990). Contrastive feministic linguistics. Mechanisms of language discrimination in English and German. Max Hueber Verlag, Ismaning. 175 p.

Horvath, L.K., Merkel, E.F., Maass, A. and Sczesny, S. (2016). Does Gender-Fair Language Pay Off? The Social Perception of Professions from a Cross-Linguistic Perspective. Front. Psychol, 6. doi: 10.3389/fpsyg.2015.02018

Ismagulova, G. (2005). Linguocultural aspect of the gender relations: comparison of the German, Kazakh and Russian languages / dissertation on cand. sc., Tjumen- $178 \mathrm{p}$.

Kirilina, A.V. (1997). Category of a gender in linguistics. Women in the Russian society.- Moscow- p. 80-91.

Kirilina, A.V. (1998). Development of gender researches in linguistics. Philological sciences. p. 51-58.

Kirilina, A.V. (2000). Gender aspects of language and communication. Doctoral dissertation of philological sciences. 35.

Kirilina, A.V. (2000). On the use of concept a gender in the Russian-language language description Philological sciences. 2000(3). p. $18-27$.

Maltz, D., Borker R. (1991). Misunderstanding between men and women - from a cultural line item female and man's speaking compared in cultural. Frankfurt. 196-211

Mamaeva, G.B. (2003). Features of the use of lexicon by women and men / dissertation on cand. of sc., Almaty.

Pusch, L. (1984). German as language of men. Compositions and glosses to feministic linguistics. Frankfurt.

Samel, I. (2000). Introduction to feministic linguistics. Berlin: Erich Schmidt Verlag.

Sarsembaeva R.B. (2004). Market transformation of the Kazakhstani society: experience of the gender analysis. Verlag «LEM», Almaty, 2004, 252 p.

Sczesny, S., Formanowicz, M., Moser, F. (2016). Can Gender-Fair Language Reduce Gender Stereotyping and Discrimination? Front. Psychol, 7(25). doi: 10.3389/fpsyg.2016.00025

Tolstokorova, A.V. (1997). Linguistic statement of gender: Results and perspectives demographic reforms. Women in the history: an opportunity to be visible. Collection of scientific reports under I.R. Tschikalova. Minsk: BSPU, 3, 50-71.

Tolstokorova, A.V. (2005). Gender and sensitive language reform as element of global social policy. Journal on researches of social policy, 1, 87-110.

Trömel-Plötz, S. (1988). Female language as a language of changes. Zürich: 219 p.

Trömmel-Plötz, S. (1992). Language of fathers of Native language. Observations on language and a policy. p. 134-146.

UNESCO. (1999). Guidelines on gender-neutral language. Paris: UNESCO, (third edition).

United Nations Organization. (1998). Editorial directive on gender-neutral language.

Voronina, O.A. (2001). Theoretical and methodological bases of gender researches. Theory and methodology of gender researches under Unter Red. - M.: MZGI. 